\title{
ВЕРХНИЙ КУЛЬТУРНЫЙ ГОРИЗОНТ ПАМЯТНИКА КАМЕННОГО ВЕКА ЭКИБАСТУЗ-4
}

\author{
(C) 2020 г. В. С. Волошин
}

В статье даётся описание кварцитового инвентаря из верхнего культурного горизонта памятника каменного века Экибастуз-4, полученного в зачистке 1988 г. Приводится характеристика специфического типа индустрии, для которой свойственны: в первичном расщеплении - сочетание нижне-среднепалеолитических приёмов скалывания отщепов и верхнепалеолитических приёмов снятия пластин, во вторичном расщеплении - тейякский компонент, широкое развитие техники рассечения заготовок и комбинаторика рабочих частей (элементов) орудий, серия специфических вкладышевых орудий из отщепов, а также двухстороннеобработанные орудия. Предложена хронологическая схема распределения археологических памятников Левобережного Прииртышья возрастом от максимума сартанского оледенения до начала голоцена, в которой верхний горизонт Экибастуза-4 относится к аллерёдупребореалу (12-10 тыс. л.н.).

Ключевые слова: археология, Экибастуз-4, памятник, индустрия, орудие, рабочая часть, слой, поздний палеолит, техника

\section{Введение}

Археологический памятник Экибастуз-4 принадлежит к числу условных пунктов, выделенных среди обширных залежей кварцитов в черте построек Старого Экибастуза. Он расположен в 300 м от берега озера Экибастуз и в 530 м к юго-западу от ближайшего тригопункта с отметкой 193 м и привязан к заброшенному котловану и выбросам из него. В стратиграфической колонке, полученной на памятнике во время зачистки стенки котлована в 1988 г., положение верхнего культурного горизонта чётко определено в верхней части слоя 2 , т.е. коричневато-бурой супеси мощностью 15-23 см, залегающей поверх достаточно маломощной толщи эоловой супеси с несколькими генерациями криогенных клиньев; к основанию этой толщи приурочен изученный нами ранее нижний культурный горизонт [Волошин, 2020, рис. 1]. Эта коричневато-бурая супесь с кварцитовыми артефактами местами обнажается на поверхности, в других же местах погребена под тонким слоем (до 30 см) эоловых отложений (слой 1б) или же на пониженных участках - под современной тёмно-серой почвой (слой $1 \mathrm{a})$. В процессе разборки слоя 2 стало ясно, что к его верхней части принадлежит большая часть находок, но не все: артефакты рассеяны по всему слою и залегают в том числе в основании слоя прямо на поверхности подстилающей его серой карбонатизированной супеси - в последнем случае у предметов нижняя сторона, как правило, бывает покрыта тонкой и плотной серой карбонатизированной корочкой (таких предметов всего 6 шт.). 
Характеристика материала

В зачистке 1988 г. из слоя 2 была получена коллекция кварцитовых артефактов в количестве 147 предметов, основная масса последних состояла из качественного тонкозернистого светло-серого кварцита. Все предметы относятся к группе со «свежей» фактурой, имеют острые (не заглаженные эоловой корразией) края и поверхности, часть из них с одной стороны покрыта лёгкой белой патиной. Ниже даётся технико-типологическое описание артефактов.

Нуклеусы - 7 шт. Здесь обращает на себя внимание крупное и двухстороннее площадочное-плоскостное ядрище $(19,7 \times 8,8 \times 5,5 \quad$ см $)$ с двумя негативами встречных удлинённых отщепов на одной стороне и с серией негативов отщепов в поперечном направлении на противоположной стороне (рис. 1, 1), у которого одна из концевых ударных площадок носит следы пластинчатого фасетирования; в целом нуклеус нельзя отнести к группе приготовленных, расщепление велось с помощью тяжёлого отбойника. Ещё одна форма площадочноплоскостных нуклеусов представлена образцом небольшого короткого двухплощадочного одностороннего встречного нуклеуса в начальной стадии утилизации $(8,7 \times 7,4 \times 2,9$ см), на рабочей поверхности которого наблюдается негатив ассиметричного отщепа, снятого тяжёлым отбойником от гладкой ударной площадки по фронтальному ребру; в основании имеется фасетированная скошенная ударная площадка, подготовленная для снятия встречного фронтального отщепа.

Имеются также краевые нуклеусы для пластин (2 шт). Один из них грубо приготовлен отдельными расколами и фасами из бло-
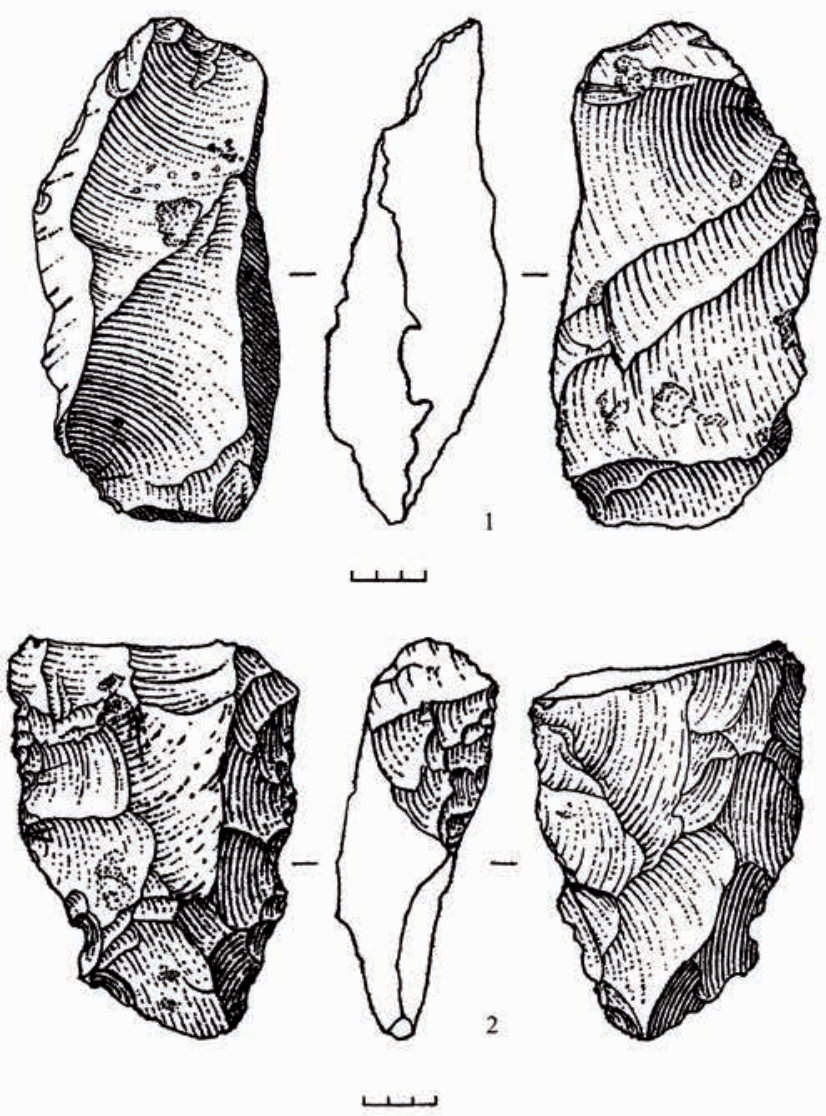

Рис. 1. Экибастуз-4. Кваричитовые артефактьл. 1-2-нуклеусы

Fig. 1. Ekibastuz-4. Quartzitic artifacts. 1-2 - lithic cores 
ка, имеет четырёхугольную форму $(14,2 \times 10,3 \times 4,8$ см). На рабочей боковой стороне наблюдается два пластинчатых негатива: первый - от пластины, снятой по ребру, второй, заломившийся - от некондиционной заготовки, снятой по оси первой пластины; расщепление велось с помощью тяжёлого отбойника. Ещё одна сходная форма представлена фрагментом (верхняя часть) маленького нуклеуса для ножевидных пластинок (рис. 9, 12); ударная площадка у него скошенная фасетированная, при расщеплении использовался посредник. ских нуклеусов - укороченных ассиметричных и исполненных в технике тщательной двухсторонней отделки. Первый образец представляет собой заготовку относительно небольшого нуклеуса $(7,8 \times 10,2 \times 3,0$ см $)$ с узкой фасетированной скошенной ударной площадкой на углу, смежном с боковой плоскостью поперечного раскола (рис. 3, 3); большая часть периметра такого ассиметричного нуклеуса является дугообразным клином, а более выпуклая тщательно оформленная фронтальная поверхность позволяет

\section{Заготовка кли-} новидного нуклеуса для пластин (рис. 2, 3) изготовлена из плоского обломка и имеет достаточно крупные размеры и укороченные пропорции $(11,2 \times 13,1 \times 3,2 \quad$ см $)$; скошенная ударная площадка и фронтальная часть представляют собой плоскости поперечного раскола, a сильно выпуклый боковой клин тщательно оформлен двухсторонними фасетками; изделие с одной из латеральных сторон тщательно уплощено серией фасов и фасеток от ударной площадки. Данный предмет с одной из сторон покрыт карбонатизированной корочкой.

В заключение отметим наличие в коллекции формы весьма специфиче-

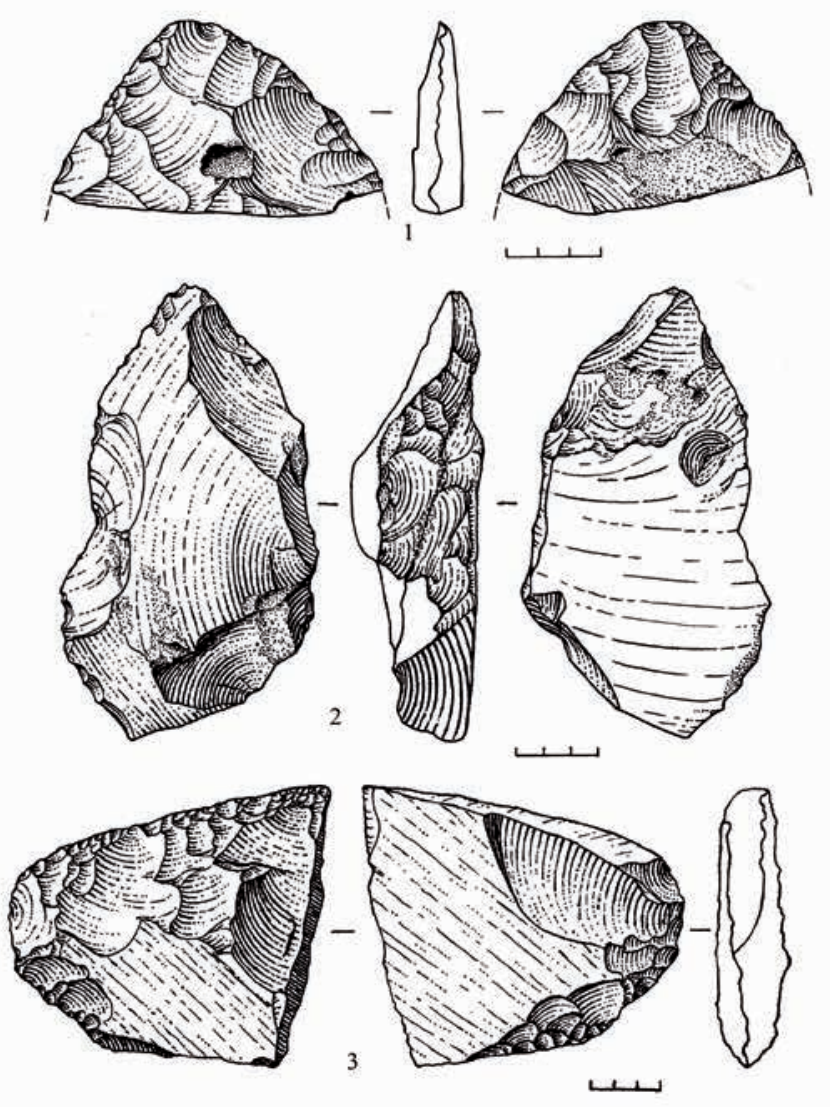

Рис. 2. Экибастуз-4. Квариитовые артефакты: 1 - фрагмент бифаса; 2 - крупное остроконечное орудие; 3 - заготовка клиновидного нуклеуса

Fig. 2. Ekibastuz-4. Quartzitic artifacts: 1 - biface fragment; 2 - large sharp-pointed tool; 3 -wedge lithic core blank 


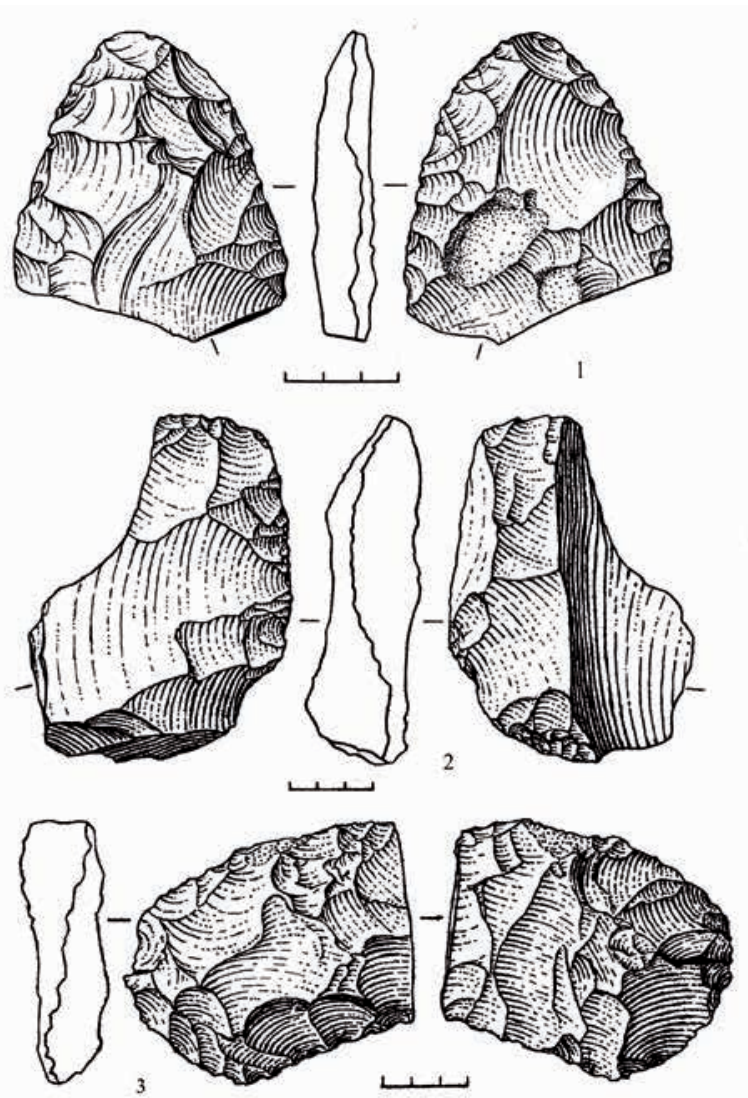

Рис. 3. Экибастуз-4. Кваричитовые артефакты: 1 -бифас; 2 - скребло,

3 - заготовка клиновидного нуклеуса

Fig. 3. Ekibastuz-4. Quartzitic artifacts: 1 -biface;

2 -scraper; 3 -wedge lithic core blank

обработанного нуклеуса с боковой обушковой гранью от поперечного раскола, но ударная площадка, также фасетированная и скошенная, отличается здесь большей шириной, а фронтальная сторона, наоборот, уже более плоская, ввиду начавшегося процесса утилизации нуклеуса (с использованием мягкого отбойника). Представляется, что с общей технологической стороны данная форма ядрища представляет собой значительное развитие известной формы нуклеусов пара-леваллуа виктория-вест из ашеля Африки, которые использовались в индустриях конца раннего ашеля для производства крупных отщеповзаготовок под кливеры. В некоторых раннепалеолитических комплексах Сарыарки, в частности в средней серии Жуантюбе 1 , данная форма нуклеусов уже была известна и при-

снять от ударной площадки поперёк длинной оси изделия, т.е. вдоль боковой обушковой грани отщеп нужных кондиций - что-то среднее между обушковым отщепом и плоским черепаховидным отщепом леваллуа. Второй образец отличается более крупными размерами $(11,5 \times 18,5 \times 4,9$ см), но также тщательно отделан в технике двухсторонней обработки и имеет линзовидное поперечное сечение (рис. 1,2$)$; одна из сторон его покрыта карбонатизированной корочкой. Здесь также - форма укороченного ассиметричного двухсторонне- готавливалась уже подчас не менее тщательно, чем в данном случае.

Двухсторонние орудия - 2 шт. Первое изделие - это фрагмент (концевая часть) широкого и плоского бифаса листовидной формы с толщиной на изломе в 1,9 см; изделие оформлено пологими и плоскими, короткими и чешуйчатыми фасами и фасетками, края ровные и острые, сечение - правильное линзовидное; с обеих сторон сохранились небольшие участки естественной поверхности заготовки (рис. 2, 1). Второе изделие представлено, вероятно, целым эк- 
земпляром (рис. 3, 1) - изломы в основании правильнее рассматривать как плоскости намеренного поперечного рассечения бифаса с целью последующего его крепления нижней усечённой частью в рукоять. Таким образом, это бифасный клевец $(8,3 \times 7,1 \times 1,3 \quad \mathrm{~cm})$. Изделие в поперечнике плосковыпуклое, с ровными боковыми краями и тщательно отделано пологими и плоскими фасами и фасетками, иногда дающими заломы. Бифасные клевцы под т реугольной формы известны среди материалов ряда памятников голоценового во3раста Сарыарки, в частности, на карагандинских стоян-
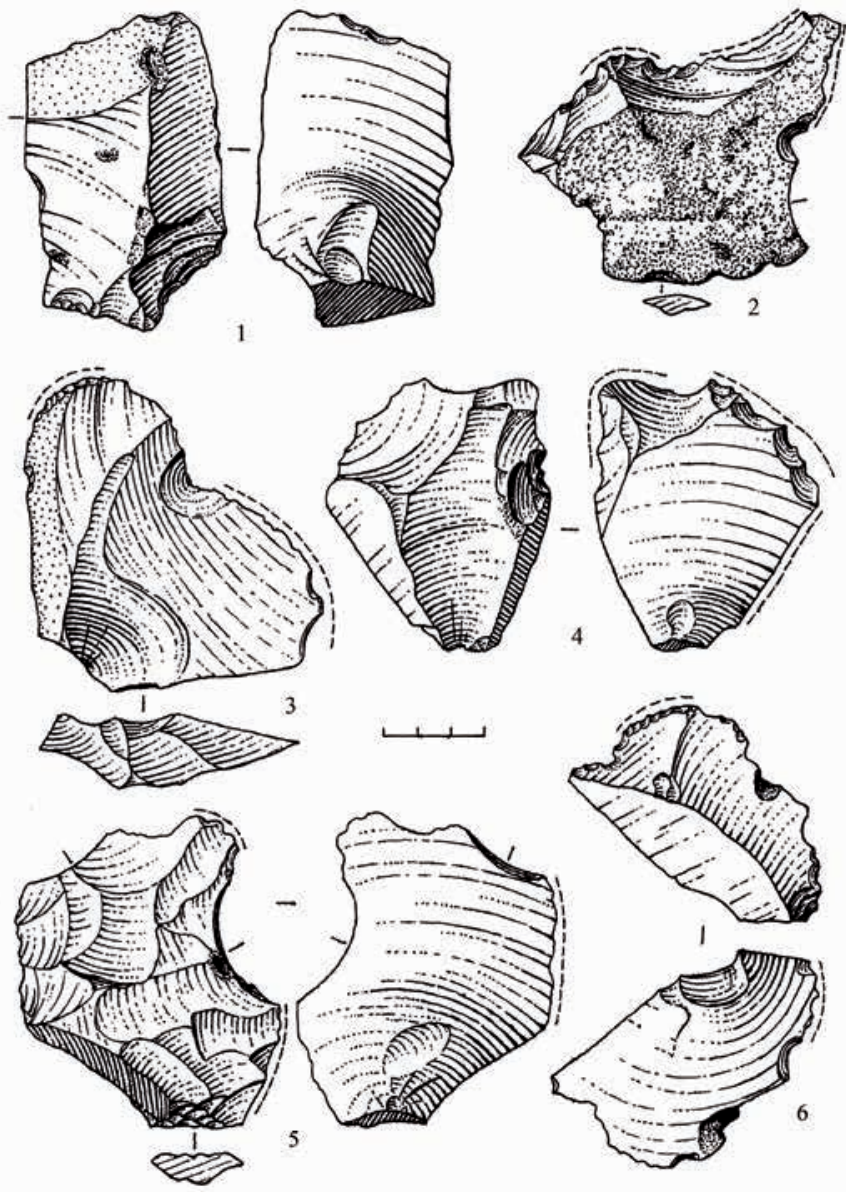

Рис. 4. Экибастуз-4. Кваричтовые артефакты: 1, 5-режущиче орудия; 2, 3, 6-скребки; 4-зубчатое орудие

Fig. 4. Ekibastuz-4. Quartzitic artifacts: 1, 5-cutting tools; 2, 3, 6-scrapers; 4-serrated tool

\section{ках, исследованных}

М. Н. Клапчуком в Талапкере 1 и Селетинском.

Орудия из обломков и крупных отщепов - 8 шт. В данную группу отнесены орудия, длиной превышающие 12 см. Это, прежде всего, изготовленный из массивного обломка породы струг с прямым лезвием на конце, оформленным скупо-лицевым полукрутым фасом и мелкими фасетками $(12,7 \times 5,9 \times 3,4$ см); в конструктивных целях изделие по боковому краю тщательно отделано лицевой крутой и отвесной отёсывающей ретушью. У данного орудия помимо лезвия струга на противоположном конце с помощью крутой ретуши оформлено лезвие зубчатого скобеля, а на углу - альтернативными фасетками поперечная резцевидная кромка (1,2 см). Ещё одно орудие изготовлено из фрагментированного нуклеуca $(12,3 \times 9,2 \times 3,5$ см $)$ - это боковое скребло с широким выпуклым в плане и в профиль лезвием с тщательной пологой распространённой и чешуй- 
чатой ретушью (рис. 3, 2). Остальные орудия изготовлены из крупных отщепов: использовались обычно массивные отщепы укороченных пропорций, снятые при помощи тяжёлого отбойника, и в одном случае - желобчатый укороченный отщеп с изогнутой площадкой, снятый, вероятно, с помощью посредника (рис. 5, 5). Площадки таких отщепов разные - гладкие, двухгранные и грубофасетированные.

Опишем орудия по отдельности. Удлинённое остроконечное орудие $(17,0 \times 9,3 \times 4,0$ см), плоско- выпуклое в поперечнике, частичнобифасиальное; рабочая остроконечная часть оформлена двухсторонними фасами, занимает одну треть длины орудия, имеет острые слегка извилистые края и завершается на окончании острой извилистой кромкой. Внутренний край орудия обушковый - притуплен отвесными фасами и фасетками. Внешний - более тонкий и острый, оформлен с лицевой стороны приостряющим широким фасом и серией фасеток. Основание орудия скошено нижним крутым фасом и утончено двумя заломившимися лицевыми фасами (рис. 2, 2). Это рубящее орудие, вероятно, крепилось к рукоятке, т.е. является клевцом.

Орудие из массивного укороченного отщепа с широкой и толстой грубо-фасетированной площадкой $(15,3 \times 11,5 \times 3,5 \mathrm{~cm})$ имеет два рабочих элемента: короткий остроконечный выступ, оформленный вентральными фасетками на углу площадки, и режущее боковое вогнутое лезвие с выщербинками от использования.

Орудие из укороченного отщепа c широкой двухгранной площадкой $(14,6 \times 9,9 \times 2,7 \quad$ см $) \quad$ в конструктивных целях оформлено в нижней части широкой вентральной клектон-

Fig. 5. Ekibastuz-4. Quartzitic artifacts: 1-2 - cutting tools; 3 -recessed bracket; 4 -scraper; 5 -tool with protrusion 
ской выемкой и имеет три рабочих элемента: угловой выступ с альтернативными фасетками, широкое и выпуклое режущее лезвие, а также тонкое скребковидное лезвие на краю (2,4 см), выделенное с боков небольшими выемками-фасетками.

Орудие из первичного отщепа с гладкой площадкой $(12,5 \times 6,9 \times 2,5$ см) представляет собой угловой резчик, конструктивно оформленный широким косым сечением, создавшим обушок, а также небольшими двухсторонними фасетками.

Орудие из укороченного отщепа с широкой грубо-фасетированной площадкой $(13,3 \times 9,0 \times 2,2 \quad$ см $)$ имеет два рабочих элемента: выпуклое режущее лезвие, выделенное с боку небольшим выемчатым сечением, а также режущее зубчатое лезвие с фасетками и выемками с двух сторон.

Орудие из укороченного отщепа с гладкой изогнутой площадкой $(14,3 \times 7,3 \times 1,8 \quad$ см $)$ имеет три рабочих элемента: остроконечная часть, треугольная в сечении, с двумя ретушированными шипами на окончании и смежным острым (режущим) краем; лезвие зубчатого скобеля с крутой дорзальной ретушью, а также режущее лезвие на боковом краю, ограниченное с боку небольшим сечением (рис. 5, 5).

Пластины и орудия из них 10 шт. Все представленные здесь пластины широкие, т.е. шириной более 2 см; призматические формы отсутствуют. Наиболее выразительны два изделия с гладкими скошенными площадками, снятые тяжёлым отбойником (рис. 7, 10-11); острые боковые края с отдельными микрофасетками и выщербинками и сечёные дистальные концы позволяют считать их режущими орудиями. Ещё одно 


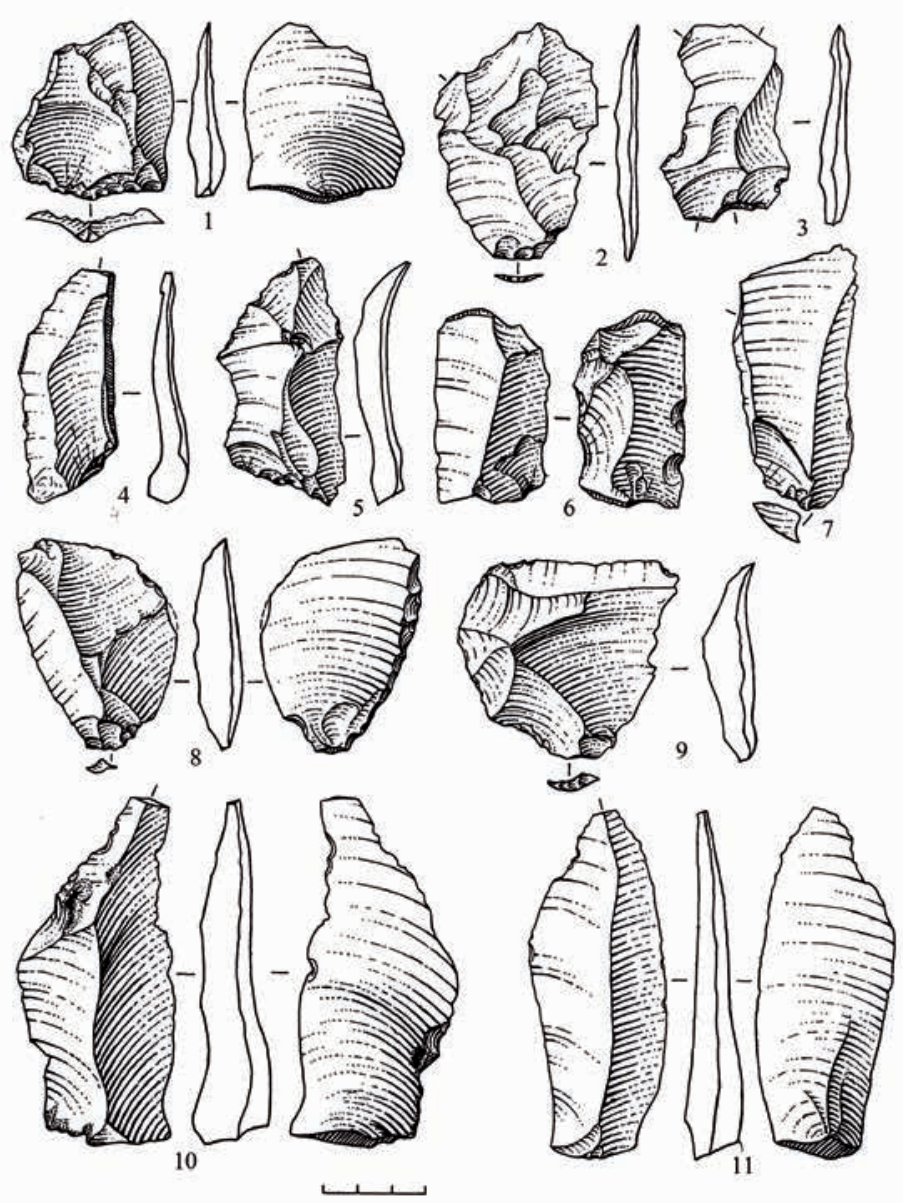

Рис. 7. Экибастуз-4. Квариитовые артефакты:

1-2, 5, 9-11-режущие орудия; 3-выемчатый скобель; 4, 6-8-ножи с обушком

Fig. 7. Ekibastuz-4. Quartzitic artifacts:

1-2, 5, 9-11-cuttingg tools; 3 - recessed bracket; 4, 6-8-knives with hack

лено фрагментом - это концевой микро-скребок с тонким прямым лезвием $(0,7$ см), о формленным д о р з а ль н о й микро-ретушью и выделенным с боков небольшими угловыми сечениями (рис. 9, 2). В собрании имеется также пластина с вентральноретушированной выемкой на краю $(4,5 \times 2,1 \times 0,5 \mathrm{~cm})$; у неё маленькая фасетированная площадка и дистальное сечение. Последние два изделия из пластин - вероятно, вкладыши: одно из них представляет собой дистальное сечение $(4,8 \times 3,7 \times 0,6 \quad \mathrm{~cm})$ c черешком в основании и острыми лезвия-

режущее орудие на тонкой и плоской пластине $(6,4 \times 3,5 \times 0,7$ см) оформлено небольшими сечениями и выемками. Два изделия являются ножами с боковым обушком-гранью: одно из них $(6,8 \times 2,8 \times 0,4$ см $)$ с дистальным сечением (рис. 7,4$)$, другое $(7,5 \times 3,4 \times 0,8$ см) - с угловым сечением (рис. 7, 7). Одно изделие изготовлено из среднего сечения пластины $(4,5 \times 4,9 \times 1,0 \mathrm{~cm})$ и представляет собой угловой резчик (рис. 8,1$)$. Ещё одно изделие представ- ми на уголках, вставлялось в торец
рукоятки режущего орудия, другое представлено фрагментом сечения пластины.

Орудия из отщепов и сколов - 94 шт. Это основная масса орудий в коллекции. Прежде всего укажем на некоторые общие техникотипологические черты данного собрания орудий. Максимальная длина изделий варьирует в пределах 3-12 см, медиальное положение занимают 
изделия длиной 5-6 см (25 шт.). Толщина варьирует в пределах 0,4-3,5 см, медиальное значение - 0,6-1,0 cм (47 шт.). Из 61 определимых объекта у 29 заготовка снята тяжёлым отбойником, столько же отщепов снято лёгким отбойником, и только в трёх случаях можно говорить об использовании при расщеплении посредника. Значительное большинство исходных заготовок - это вторичные отщепы (85 шт.), первичных заготовок нет вообще. Преобладают заготовки коротких пропорций, меньше укороченных,
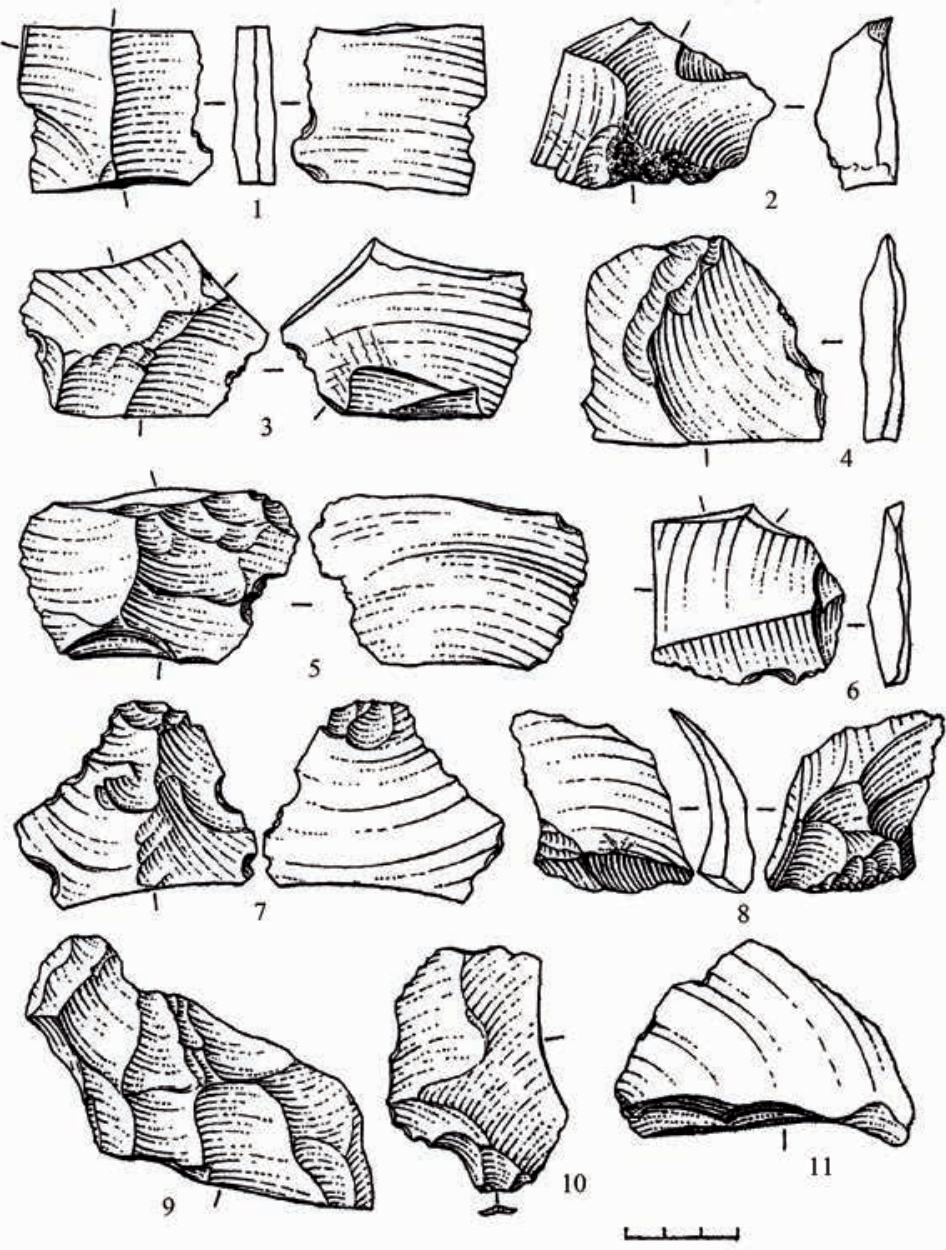

Рис. 8. Экибастуз-4. Квариитовые артефакты: 1-2 - угловые резчики; 3-5, 8, 9, 11 - режущие орудия; 6-резиевидное орудие; 7 -скребок; 10 -нож с обушком

Fig. 8. Ekibastuz-4. Quartzitic artifacts: 1-2 - angular cutters; 3-5, 8, 9, 11 -cutting tools; 6-chisel-shaped tool; 7 -scraper; 10 - knife with hack

совсем мало -

удлинённых; также преобладают тонкие и плоские заготовки, а толстых - значительно меньше; желобчатые отщепы (9 шт.) и отщепы с трапециевидным сечением (2 шт.), а также клектонские (3 шт.) и леваллуазские (6 шт.) немногочисленны. Среди последних - 5 черепаховидных. Имеется серия отщепов с боковым обушком - для данной группы это вполне нормальное явление. Есть один небольшой бивентральный отщеп, который был использован под вкладышевое орудие. У 12 изделий площадки заготовок были отсечены или удалены иным образом. Среди сохранившихся площадок - гладкие (23 шт.), двухгранные (5 шт.), грубофасетированные (8 шт.), фасетированые (7 шт.), натуральные (3 шт.); но больше всего маленьких, тонких, почти точечных площадок (27 шт.) и 
только одна изогнутая. Большинство площадок скошенные и сильно скошенные. В 16 случаях на внешних краях площадок наблюдается бахрома в виде серии уплощающих или выравнивающих поверхность заготовок фасеток. В единичных случаях использовались реберчатые и массивные, брусковидные формы заготовок.

Необходимо отметить, что приёмы широкого рассечения заготовок, а также узкое сечение на уголках и выступах заготовок, вообще интенсивность рассечения - это одна из важнейших черт «свежих» кварцитовых индустрий Экибастуза. В первом случае, т.е. при широком рассечении заготовки, задавалась общая форма орудия или вкладыша орудия, оформлялся обушок и удалялась площадка заготовки. При узких, небольших и, чаще всего, вогнутых сечениях про-
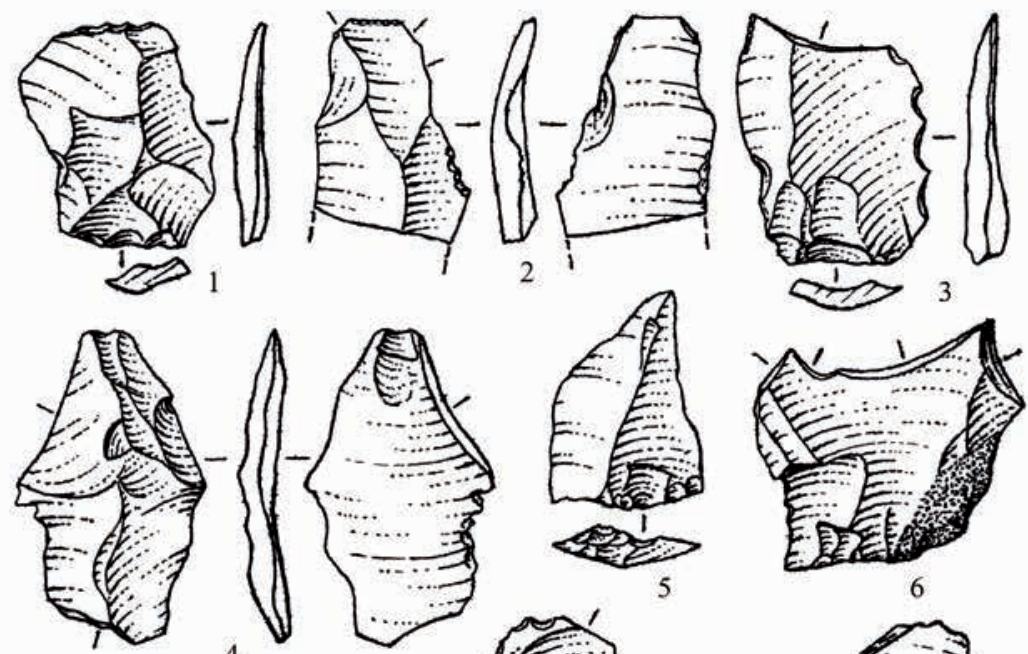

6

4
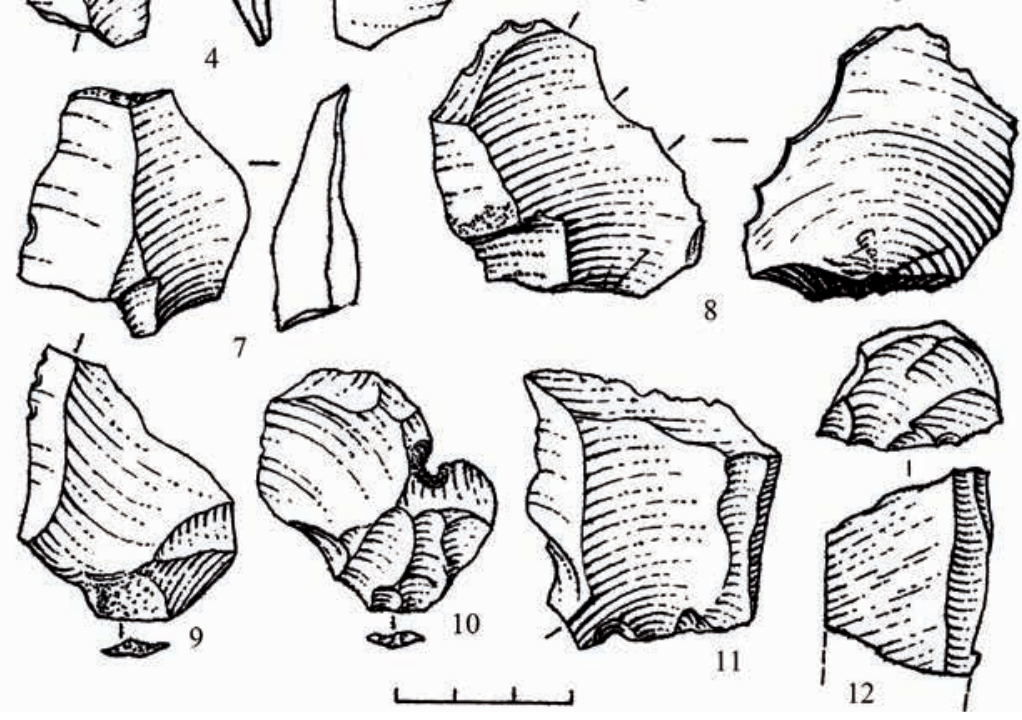

Рис. 9. Экибастуз-4. Квариитовые артефакты: 1, 5, 7-11-режущие орудия;

2 -микроскребок; 3 - проколка; 4 -вкладыш; 6-орудие с выступами; 12 - фрагмент нуклеуса

Fig. 9. Ekibastuz-4. Quartzitic artifacts: 1, 5, 7-11-cutting tools; 2-microscraper; 3 -piercer; 4 -insert; 6 -tool with protrusions; 12 -fragment of lithic core 
изводились локальные модификации орудий, в том числе с одного или обоих боков выделялся рабочий элемент - режущее, скребковидное или иное лезвие, составляющее функциональную особенность орудия. Кстати, подобную же роль в индустрии исполняли отдельные чешуйчатые выемки-фасетки, тейякские выемки, микровыемки и микрофасетки. Последние два типа выемок наносились и на режущие лезвия орудий для придания им большей эффективности. Ещё одной особенностью орудийного набора является полное отсутствие здесь протяжённого ретушированного края, т.е. скрёбел, остроконечников, острий, притупленных спинок ножей и т.д. Ретушь на орудиях всегда локализована и формирует выступы, выемки, зубчики и другие узкие участки краёв, что вкупе с сечениями и отсутствием типичных форм скрёбел, скребков, острий, резцов и всего известного прочего неизбежно оставляет здесь впечатление «тейяка». Из общего собрания орудий выделены следующие группы.

Ножи боковые - 11 шт. Почти все они имеют на противоположном краю обушок - натуральный (1 шт.), в виде одной грани (1 шт.) или из нескольких граней (3 шт.), в виде одного или нескольких сечений (рис. 10, 10), в том числе дополнительно с сечёным концом (рис. 8, 10) - всего таких ножей 4 шт.; имеется также один нож с вентрально-притупленным обушком, а также один нож с вентральноутончённой спинкой (рис. 7, б). В одном случае у ножа с гранёным обушком и сечёным концом бюльб отщепа подвергся утончению вентральными фасетками.

Режущие орудия - 36 шт. Это самая распространённая и самая про- стая группа орудий - помимо указанного числа в различных сочетаниях с орудиями других групп выявлено ещё 30 режущих лезвий. Обычно лезвие охватывает один из участков края отщепа, в частности боковой край (рис. 5, 2), и у отщепа леваллуа (рис. 7,1 ); иногда носит угловатый характер (рис. 6,$1 ; 8,11 ; 9,11$ ) или имеет конвергентные очертания (рис. 9, 5; 8, 8). Иногда лезвие наделяли небольшими выемками или зубчиками для усиления эффективности режущей функции. Чаще всего, режущие орудия подвергались рассечению: на боковом краю (рис. 9, 8) или конце (рис. 7, 5; 9, 9), иногда отсекалась базальная часть отщепа (рис. 8, 9), площадка отщепа или заготовка рассекалась наискось (рис. 10, 12); в иных случаях режущие лезвия располагаются на боковых краях сечений - укороченных средних (рис. 8, 3, 5), концевых (рис. 8, 4) или иных (рис. 7, 3). У одного орудия площадка заготовки удалена вентральной чешуйчатой ретушью. Другое орудие имеет транкированный конец (рис. 9, 1). Некоторые отщепы имеют режущее лезвие по всему периметру (рис. 7, 9) и, в частности, черепаховидные отщепы (рис. 4, 5; 7, 2; 9, 10).

Зубчатые скобели - 3 шт. Один из них изготовлен из короткого желобчатого отщепа и имеет вентрально-ретушированное лезвие на широком конце (рис. 4, 4) - здесь наблюдается сочетание с массивным, трёхгранным в сечении угловым выступом, оформленным альтернативными фасетками, а также с боковым прямым режущим лезвием. Другое орудие представляет собой боковой зубчато-ретушированный скобель, ограниченный с одного бока сечением - напротив лезвия находится обу- 

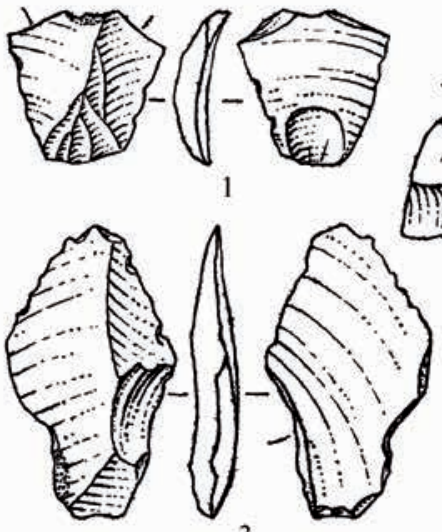

3
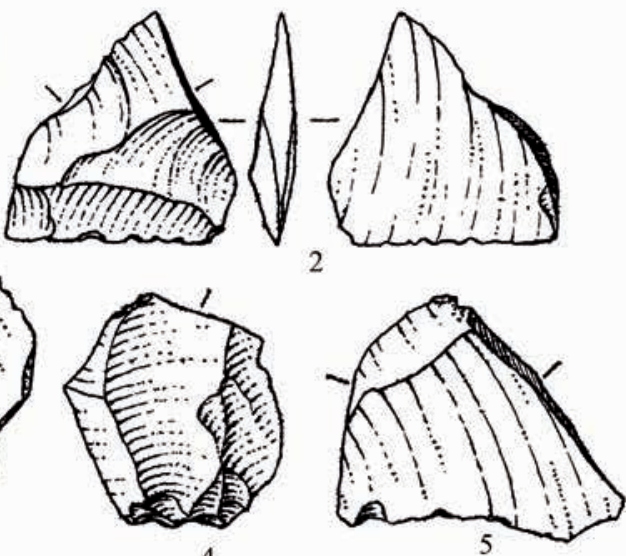

4
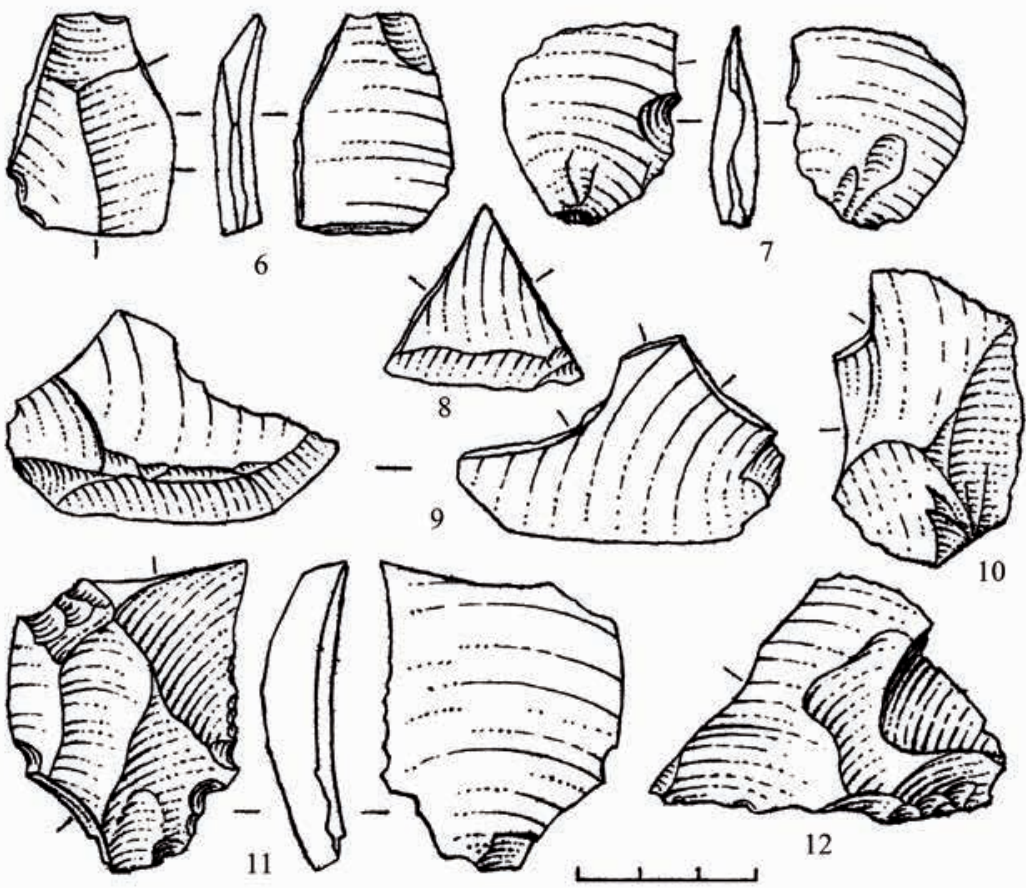

Рис. 10. Экибастуз-4. Квариитовые артефакты: 1-9, 12 - вкладыши; 10 - нож с обушком; 11 - режущее орудие

Fig. 10. Ekibastuz-4. Quartzitic artifacts: 1-9, 12 - inserts; 10 - knife with hack; 11 - cutting tool

шок в виде дорзальной грани; здесь также имеется сочетание с другим элементом - угловым шиповидным выступом, оформленным альтернативными микрофасетками (рис. 6, 5). Третий образец представлен фрагментом зубчато-выемчатого орудия с концевым сечением. В орудийном наборе есть ещё один рабочий элемент зубчатого бокового скобеля - в сочетании с другим типом орудия.

Выемчатые скобели - 3 шт. Одно орудие изготовлено из ассиметричного отщепа и имеет вентрально- 
Волошин B.C. Верхний культурный горизонт памятника каменного века Экибастуз-4

ретушированную выемку в базальной части (рис. 5, 3) - имеется сочетание с двумя режущими лезвиями, шиповидным выступом и скребковидным лезвием. На другом орудии также наблюдается сочетание выемчатого скобеля с шиповидным выступом и режущим вогнутым лезвием. На третьем орудии выемчатый скобель сочетается с резцевидным элементом. Ещё два лезвия выемчатого скобеля встречены на орудиях других типов.

Орудия с выступами - 4 шт. Одно из них с толстым выступом, оформленным боковым сечением и имеющим на окончании поперечную режущую кромку (0,3 см) - комбинируется с выемчатым скобелем и режущими лезвиями (рис. 6, 3). Другое орудие имеет форму сегмента - пара тонких шиповидных выступов комбинируется здесь с режущими лезвиями, однако, не исключено, что в данном случае перед нами крупный прямоосный вкладыш (рис. 6, 6). Ещё одно орудие имеет два шиповидных выступа, оформленных несколькими сечениями (рис. 9, 6). Последнее орудие имеет выступ с боковой выемкой на базальном углу отщепа. Ещё четыре рабочих выступа находятся в различной комбинации на орудиях других типов.

Угловые резчики - 5 шт. У одного орудия элемент углового резчика оформлен вентральной клектонской выемкой и сочетается с боковым режущим лезвием (рис. 6, 8). Другое орудие изготовлено из сечения отщепа (рис. 8, 2). Остальные орудия изготовлены ретушью и небольшими сечениями.

Скребковидные орудия - 9 шт. У одного орудия лезвие оформлено крутой дорзальной ретушью на широком поперечном краю (рис. 4,2 ) и сочета- ется с двумя режущими элементами. У другого орудия лезвие оформлено на конце отщепа краевой ретушью (рис. 4,3 ) и сочетается также с режущим элементом, оформленным клектонской выемкой. У третьего орудия аналогичное лезвие сочетается с ретушированным скребущим участком в базальной части ассиметричного отщепа (рис. 4, б). У четвёртого орудия имеется два скребковидных лезвия: тонко-ретушированное лезвие на дистальном конце и двухстороннеобработанное лезвие с боковой выемкой на месте площадки ассиметричного отщепа (рис. 5, 1) - орудие комбинировано с двумя режущими лезвиями. У пятого орудия тонкоретушированное лезвие находится на углу ассиметричного отщепа (рис. 5, 4) и комбинируется с двумя боковыми режущими лезвиями. У шестого орудия аналогичное лезвие на дистальном углу выделено с боков выемчатыми сечениями (рис. 6, 2). Ещё одно двухсторонне-обработанное скребковидное лезвие на месте площадки рассечённого отщепа наблюдается на изделии с комбинацией с зубчатым скобелем и зубчатым режущим лезвием (рис. 8, 7). Остальные орудия сходны с описанными - типичные скребки отсутствуют.

Проколки-острия - 5 шт. На одном орудии тонкое шиповидное остриё оформлено с боков сечением и ретушированной выемкой и сочетается с боковым режущим лезвием (рис. 6, 4). Другое орудие во многом сходно с ним (рис. 6, 7). У третьего орудия жало проколки оформлено косым дистальным сечением и тонкой краевой ретушью (рис. 9, 3). Остальные орудия повторяют описанные формы. Два элемента «проколки» находятся в различном сочетании на орудиях других типов. 
Резцы и резцевидные орудия 1 шт. Это совсем нехарактерная группа орудий. Изделие с тонкой поперечной резцевидной кромкой $(0,2$ см) на углу больше напоминает сечёный вкладыш из отщепа с тонким режущим лезвием на боку (рис. 8, б). Имеется ещё один элемент с плоским резцовым сколом среди орудий других типов.

Долотовидные орудия - 1 шт. Также нехарактерная группа орудий - совсем не типичное лезвие с вентральным фасом на узком боку укороченного среднего сечения отщепа находится в сочетании с выемчатым скобелем.

Вкладышевые орудия - 16 шт. Почти всегда это сечёные формы отщепов, минимально подвергнутые ретушированию. Среди них есть группа изделий (7 шт.), которые, вероятно, вставлялись в торец рукоятки. Отметим, прежде всего, небольшое орудие из короткого отщепа $(5,0 \times 3,9 \times 1,1 \mathrm{~cm})$ с двумя боковыми острыми лезвиями и косым дистальным сечением (рис. 10, 11): правое вогнутое лезвие носит следы дорзальной ретуши, левое выпуклое - выделено с боков выемкамифасетками, а в основании с помощью бокового вогнутого сечения и двухсторонних фасеток оформлен лёгкий черешок; данное орудие вполне могло служить вкладышем в торец рукоятки составного режущего орудия. Другое черешковое изделие $(4,8 \times 2,7 \times 0,6$ см) имеет в верхней части конвергентно сходящиеся боковые острые лезвия, черешок оформлен косым сечением и вентральной ретушью (рис. 10, 3). У третьего изделия черешок едва намечен косым сечением в нижней части плоского удлинённого отщепа $(5,3 \times 3,2 \times 0,4$ см $)$ и утончён двухсторонними фасетками (рис. 9, 4), оба боковых края острые, дистальный конец наискось усечён. Ещё одно изделие отличается маленькими размерами $(2,4 \times 2,6 \times 0,6 \mathrm{~cm})$, изготовлено из мелкого скола; основание-насад здесь утончено вентральной фасеткой, а оба боковых края ровные и острые и ограничены на верхних уголках небольшими косыми сечениями (рис. 10, 1). Пятое изделие изготовлено из короткого и плоского желобчатого отщепа и также с косым дистальным сечением и боковыми острыми краями $(3,9 \times 3,9 \times 0,5 \mathrm{~cm})$, площадка отщепа здесь удалена дорзальными фасетками (рис. 10, 4). Шестое изделие $(5,5 \times 3,5 \times 0,6$ см) имеет один острый боковой край напротив сечёного угловатого края, на месте удалённой площадки вогнутым сечением и фасетками намечен черешок (рис. 10, 9). Последнее изделие данной группы $(3,8 \times 2,8 \times 0,7$ см $)-$ короткое и подпрямоугольной формы, с сечёным основанием и дистальным узким поперечным (долотовидным) лезвием, приострённым плоской вентральной фасеткой (рис. 10, б).

Ещё одну группу составляют подтреугольные сечёные формы отщепов (3 шт.), среди которых наиболее выразительно симметричное маленькое $(3,4 \times 3,1 \times 0,5$ см) изделие (рис. 10, 8); два других изделия покрупнее, но также ровные и плоские в профиль и имеют острое лезвие в основании (рис. 10, 2, 5). Среди вкладышей имеется форма из отщепа с сечёным дистальным концом и натуральным боковым обушком напротив острого лезвия $(4,1 \times 2,6 \times 0,6$ см), у которого площадка удалена двухсторонними фасетками. Также имеется четыре маленьких укороченных сечения отщепов с острыми боковыми краями. Отметим также на- 
Волошин B.C. Верхний культурный горизонт памятника каменного века Экибастуз-4

личие изделия, изготовленного из небольшого бивентрального отщепа $(3,5 \times 3,1 \times 0,6$ см), один из краёв которого усечён небольшим сечением и выемкой-фасеткой (рис. 10, 7).

Отщепы и сколы - 24 шт. Здесь имеются целые отщепы (12 шт.), среди которых наиболее выразительны небольшой клектонский отщеп с гладкой толстой и скошенной площадкой $(5,2 \times 7,0 \times 2,5$ см $)$ и укороченный желобчатый, брусковидный отщеп с широкой гладкой и скошенной площадкой, а также их фрагменты (8 шт.) и мелкие сколы (4 шт.).

Таков каменный инвентарь верхнего культурного горизонта памятника Экибастуз-4. Многие изделия, а также уже отмеченные выше технико-типологические черты и особенности здесь аналогичны инвентарю нижнего горизонта [Волошин, 2020]. Это объясняется, с одной стороны, общностью используемого и там и здесь кварцитового сырья, с другой стороны, безусловной культурной преемственностью между комплексами - последнее обстоятельство однозначно свидетельствует в пользу достаточно короткого разделяющего их временного интервала, в точение которого была отложена полутораметровая толща эоловой пылеватой супеси с криогенными образованиями. Здесь нужно иметь в виду и другое обстоятельство. Обитатели верхнего горизонта добывали кварцитовое сырьё из того же самого эоценового пласта, что и поселенцы, оставившие нижний горизонт артефактов, и для этого они были вынуждены проделывать в эоловой дюне узкие траншеи (одна из таких траншей зафиксирована в стенке нашей зачистки) - естественно, что вместе с блоками кварцита на поверхность должна была выбрасы- ваться продукция нижнего горизонта, столь же «свежая», как тут же расщепляемый материал. Впрочем, на поверхностях нескольких артефактов из верхнего горизонта эти различия возраста всё-таки нашли своё отражение в виде едва заметной «суперпозиции фасов». Таким образом, не «чистый», а в какой-то степени смешанный характер инвентаря верхнего горизонта здесь вполне естественен. Это было смешение элементов разных этапов, в общем-то, одного и того же культурного пласта.

Последний характеризуется вполне определённо. В технике первичного расщепления - это сочетание нижне-среднепалеолитических приёмов и типов (площадочноплоскостные нуклеусы, клектонские, пара-леваллуазские и черепаховидные приёмы расщепления) с позднепалеолитическими (краевые и клиновидные нуклеусы, техника пластин, использование посредника). Для продукции вторичного расщепления, орудийного набора - это значительное доминирование и невыразительность, аморфность орудий из отщепов, отсутствие или редкость среди изделий протяжённого ретушированного лезвия и, наоборот, выразительный «тейякский» компонент, интенсивная практика сечения заготовок приёмами широкого рассечения и локального тонкого сечения, отсутствие или редкость типичных позднепалеолитических форм орудий - скрёбел, остроконечников и острий, скребков, резцов. Пластинчатый набор орудий носит явно подчинённый характер. Наличие вкладышей из сечений отщепов и пластин, в том числе геометрических форм и с намеченным черешком в основании. Выразительны двухсторонне обработанные орудия 
- клевцы листовидной и подтреугольной формы, ножи, а также бифасы, напоминающие известные ашельские формы.

\section{Обсуждение}

Аналоги для комплекса также определённы. Это кварцитовые материалы стоянки-мастерской Дузоке-3 [Волошин, 2011], среди которых, как нам представляется, имеются самые ранние артефакты комплекса, а также Талдыозека-21 [Волошин, 1998] (оба памятника расположены восточнее Экибастуза - в районе Майкаина); более отдалённые аналогии - памятник Баршин-3 в Тенгизской степи [Волошин, 1982]. Особенно интересно сравнение материалов из верхнего горизонта Экибастуза-4 и Талдыозека21. Последний памятник, будучи по типу узко локализованной «точкой», содержит по определению «чистый» материал и почти полностью кремневый (здесь есть только несколько артефактов из кварцита). Несмотря на это, по всем основным показателям, и даже до деталей, он сходен с Экибастузом-4 и, таким образом, не оставляет сомнений в специфичности всего культурного комплекса. Стратиграфическое положение обоих памятников также сходно. В Талдыозеке-21 артефакты залегали в эродированном сверху маломощном горизонте коричневато-бурого суглинка, заполняющего клиновидные трещины в нижележащих более светлых и карбонатизированных суглинках и супесях. Как и в Экибастузе-4, какая-то часть из них лежала непосредственно на поверхности этих последних, и с нижней поверхности эти артефакты были покрыты вследствие вытяжки солей плотной карбонатизированной корочкой.
Определение геологического возраста обоих памятников связано с уяснением положения в геохронологической шкале этого коричневатобурого горизонта (супеси или суглинка), достаточно хорошо представленного на многих памятниках среди сухостепных ландшафтов Левобережного Прииртышья. В Ангренсоре-2, стратиграфия которого детальная и хорошо нам известна, этот горизонт покрывает делювиальные суглинки на склоне, а на днище ложбины формирует отдельную делювиальнопролювиальную ритмопачку (по нашему исчислению ритмопачку IV), которая линзами дресвы и щебня неявно делится на две части и перекрывает слоистые светлые карбонатизированные суглинки ритмопачки $\mathrm{V}$, включающие две жилые поверхности финального палеолита (или раннего мезолита), и ниже - тонкую красноцветную прослойку. Выразительные криогенные образования, как и отдельные самые ранние каменные артефакты на этом памятнике, связаны с ещё более древней ритмопачкой VI.

На памятнике Шидерты-3, pacположенном на поверхности первой надпойменной террасы речки и изученным В. К. Мерцем [2008], коричневато-бурый горизонт сложен тяжёлыми суглинками и образует как бы переходную зону между верхней субаэральной частью отложений террасы, включающей три горизонта ископаемых почв и суглинки между ними, и нижней аллювиальной частью террасы, включающей две генерации клиновидных трещин и две тонких красноцветных прослойки. Насколько мне известно, здесь он отделён от нижней желтоватой глины тонкими песчано-дресвяными линзовидными 
прослойками, а также разделён на две части: верхнюю часть, к основанию которой приурочен культурный слой 5, и нижнюю часть с двумя генерациями клиньев, в основании которой находится культурный слой 6.

\section{Заключение}

Исходя из приведенных наблюдений, можно предложить следующую хронологическую схему распределения памятников данного района:

1) самые ранние позднепалеолитические материалы залегают в переотложенном состоянии в отложениях ритмопачки VI памятника Ангренсор-2, отвечающих максимуму сартанского оледенения;

2) нижний культурный горизонт Экибастуз-4 соответствует базальной линзе ритмопачки V в Ангренсоре-2 и грубообломочному аллювию первой надпойменной террасы речки
Шидерты, т.е. внутрисартанскому потеплению (18-17 тыс. л.н.);

3) две жилые поверхности позднего палеолита (раннего мезолита) в ритмопачке V Ангренсора-2 соответствуют, вероятно, первому потеплению позднеледниковья (бёллинг или 14-13 тыс. л.н.);

4) памятник Талдыозек-21, культурный слой 6 Шидерты-3, верхний горизонт Экибастуза-4 (возможно, только артефакты из нижней части слоя 2), а также часть материала из ритмопачки IV в Ангенсоре-2 соответствуют второму потеплению позднеледниковья (аллерёд или 1211 тыс. л.н.);

5) верхняя часть слоя 2 (верхнего горизонта) Экибастуза-4 и культурный слой 5 Шидерты-3 - началу голоцена (пребореал или около 10 тыс. л.н.).

\section{ЛИТЕРАТУРА}

1. Волошин В.C. Местонахождение каменного века Баршин 3 в Тенгизской степи // Вопросы археологии и этнографии Центрального Казахстана. Караганда: изд-во КарГУ, 1982. С. 42-57.

2. Волошин В.С. Памятник каменного века Талдыозек $21 / /$ Сохранение и изучение культурного наследия Алтайского края. Барнаул: изд-во АлтГУ, 1998. С. 47-50.

3. Волошин В.С. Палеолитическая стоянка-мастерская Дузоке-3 // Вопросы археологии Казахстана. Алматы: Институт археологии им. А.Х. Маргулана; НИЦИА «Бегазы-Тасмола», 2011. Вып. 3. С. 199-211.

4. Волошин В.C. Нижний культурный горизонт памятника каменного века Экибастуз-4 // Қазақстан археологиясы. 2020. № 1 (7). С. 49-68.

5. Мери В.К. Периодизация голоценовых комплексов Северного и Центрального Казахстана по материалам многослойной стоянки Шидерты 3: автореф. дис. ... канд. ист. наук. Кемерово: КемГУ, 2008. 26 с.

\section{Сведения об авторе:}

Волошин Валерий Степанович - старший научный сотрудник, Филиал Института археологии им. А.Х. Маргулана (г. Нурсултан, Казахстан); voloshin49@list.ru

\section{ЕКІБАСТҰЗ-4 ТАС ҒАСЫРЫ ЕСКЕРТКІШІНІҢ ТӨМЕНГІ МӘДЕНИ КӨКЖИЕГІ}

\section{В. С. Волошин}

Мақалада 1988 ж. жоғарғы мәдени қабатын тазалау кезінде алынған Екібастұз-4 тас ғасыры ескерткішінің кварцитті жабдықтарының сипаттамасы беріледі. Өзіне тән ерекше түрлері бар өндіріс түрлерінің мынандай сипаттамасы беріледі: бастапқы 
ыдырауда-жаңқалықтардыжарудыңтөменгі-ортапалеолиттікәдісініңжәнетілімшелерді алудың жоғарыпалеолиттік әдістерінің үйлесуі, екінші реттегі ыдырауда - тейяктік құрамдасы, дайындауды қақ бөлу техникасын және жұмыс құралдары бөлшектерінің (элементтерін) комбинаторикасын кеңінен дамыту, жаңқалықтан жасалынған қосалқы саймандардың, сондай-ақ ірі және тұрпайы жарғыш құралдардың ерекше топтамасы. Ертіс өңірінің Солтүстік жағалауындағы археологиялық ескерткіштерді ерте сартандық мұзбасудан голоценнің басталуына дейін бөлудің хронологиялық сызбасы ұсынылған, оның ішінде Екібастұз-4 жоғарғы қабаты аллерёд-пребореалға (12-10 мың. ж.б.).

Түйін сөздер: археология, Екібастұз-4, ескерткіш, өндіріс, құрал, жұмысшы бөлшегі, қабат, кейінгі палеолит, техника

\section{UPPER CULTURAL HORIZON OF THE STONE AGE MONUMENT EKIBASTUZ-4}

\section{S. Voloshin}

The article gives a description of quartzite equipment from the upper cultural horizon of the Stone Age monument Ekibastuz-4, obtained in the process of cleaning in 1988. There is given a characteristic of specific type of the industry, which has some peculiar features: in primary splitting - a combination of lower middle palaeolithic techniques of cleaving of flakes and the upper palaeolithic methods of removal of plates, in secondary splitting - a Tayacian component, broad development of technology of section of preparations and combination theory of working parts (elements) of tools, a series of specific inset tools from flakes and also bilaterally processed tools. A chronological scheme of distribution of archaeological monuments of the left-bank Irtysh Land with age from the maximum of Sartan glaciation to the beginning of the Hologene is proposed, in which the upper horizon of Ekibastuz-4 refers to the Allerod-preboreal (12-10 thousand years ago).

Keywords: archaeology, Ekibastuz-4, monument, industry, tool, working part, layer, late palaeolithic, technique

\section{REFERENCES}

1. Voloshin, V. S. 1982. In Voprosy arheologii i etnografii Centralnogo Kazahstana (Questions of archeology and ethnography of Central Kazakhstan). Karaganda: Karaganda State University Publ., 42-57 (in Russian).

2. Voloshin, V. S. 1998. In Sohranenie i izuchenie kulturnogo naslediya Altayskogo kraya (Preservation and study of the cultural heritage of the Altay region). Barnaul: Altay State University Publ., 47-50 (in Russian).

3. Voloshin, V. S. 2011. Voprosy arheologii Kazahstana (Questions of archeology of Kazakhstan), 3. Almaty: A.Kh. Margulan Institute of Archeology; "Begazy-Tasmola" Publ., 199-211 (in Russian).

4. Voloshin, V. S. 2020. Kazakhstan archeology, 1 (7), 49-68 (in Russian).

5. Merz, V. K. 2008. Periodizaciya golocenovyh kompleksov Severnogo i Centralnogo Kazahstana po materialam mnogosloynoy stoyanki Shiderty 3 (Periodization of the Holocene complexes of Northern and Central Kazakhstan based on the materials of the multi-layered Shiderty 3 site): thesis of Cand. Hist. sciences. Kemerovo: Kemerovo State University Publ. (in Russian).

\section{About the Author:}

Voloshin Valery S. Senior Researcher, Branch of the A. Kh. Margulan Archeology Institute, Nur-Sultan, Kazakhstan; voloshin49@list.ru

\footnotetext{
Мүдделер қақтығысы туралы ақпаратты ашу. Автор мүдделер қақтығысының жоқтығын мәлімдейді. / Раскрытие информации о конфликте интересов. Автор заявляет об отсутствии конфликта интересов. / Disclosure of conflict of interest information. The author claims no conflict of interest.

Мақала туралы ақпарат / Информация о статье / Information about the article. Редакцияға түсті / Поступила в редакцию / Entered the editorial office: 30.04.2020. Рецензенттер мақұлдаған / Одобрено рецензентами / Approved by reviewers: 14.05.2020. Жариялауға қабылданды / Принята к публикации / Accepted for publication: 28.05.2020.
} 